Original Research Paper

\title{
Effect of Pachyrrizus erosus Extract on the Thrips Attack Phenomenon (Thripidae) in Capsicum annuum L. Leave
}

\author{
${ }^{1}$ Tasmin Tangngareng, ${ }^{2}$ Asni Johari, ${ }^{3}$ Ratna Sari Dewi, \\ ${ }^{4}$ Desfaur Natalia, ${ }^{4}$ Hastutik Setia A and ${ }^{4}$ Muhamad Tomy \\ ${ }^{I}$ The Department of Hadith Sciences, Philosophy and Politics Ushul-Addinfaculty, \\ State Islamic Alauddin Makassar. H. M. YasinLimpo Street No 36 Samata Goa, Makassar, Indonesia \\ ${ }^{2}$ Doctoral Program of Science Education, Jambi University, Jl. H.A.Manap Telanaipura Jambi, Indonesia \\ ${ }^{3}$ The Department of English Education, The Faculty of Educational and Science, State Islamic University, \\ Syarif Hidayatullah Jakarta, Indonesia \\ ${ }^{4}$ The Department of Mathematical and Natural Science Education, Jambi University, Raya Street \\ Jambi-Ma, Bulian KM 15, Mendalo Darat, Jambi, Indonesia
}

Article history

Received: 29-08-2018

Revised: $18-10-2018$

Accepted: 23-01-2019

Corresponding Author:

Asni Johari

Doctoral Program of Science

Education, Jambi University, Jl.

H.A.Manap Telanaipura Jambi, Indonesia

Email: johari_asni@yahoo.com

\begin{abstract}
Thrips are one of the main pests of chili plants. Until now, the method of controlling pests and diseases that are considered highly effective is the chemical method. Chemical controls have a major impact on environmental damage. One alternative that can be done is to control biologically using yam seed extract (Pachyrrizus erosus Urban). This study aims to analyze the effect of yam seed extract on the Thrips attack phenomenon (Thripidae) on chili leave (Capsicum annuum L.) and determine the smallest concentration that can decrease thrips attack. Research type was experimentally using a complete randomized design with treatment of yam seed extract concentration $(0,05 \%, 0,1 \%, 0,5 \%, 1 \%, 1,5 \%, 2 \%)$ and negative control treatment, positive control and methanol with 36 experimental units. The observed phenomenon is the area of attack, the location of the attack, the part of the leaf that is attacked, the attack pattern and the color of the attack. Data analysis of attack phenomenon was done by descriptive analysis and analysis of variance test, followed by Duncan's New Multiple Range Test at $\alpha$ $=5 \%$. The results showed that yam seed extract significantly affected by thrips attack phenomenon in decreasing the extent of the attack on chili leaves and the concentration of the smallest extract and ability to suppress the thrips attack was $0.5 \%$. The phenomenon of the attack shows that the part of the leaf that is attacked is the top surface and the location of the attack on the base, middle and the tip of the leaf and the entire leaf surface. The pattern of attack varies, which is round, oval, elongated and in the shape of the number 8 , with the color of silvery attack and then turns brownish.
\end{abstract}

Keywords: Extract, Seeds of Yam, The Phenomenon of Attack, Thrips, Chili Leaves, Capsicum annum L.

\section{Introduction}

Thrips are a pest of agricultural crops, which are found in many horticultural crops such as chili plants. Damage to plants caused by thrips occurs in buds, leaves and flowers of plants. Thrips attack the plant by grinding and sucking plant tissue fluids (Johari, 2016). Severe attacks when thrips act as vector viruses, which can result in the death of plants (Ullman et al., 1995). According to Riley et al. (2011) there are 14 species of thrips that become vectors of the genus Tospovirus. Further Lakshmi et al. (1995) states that in some species of plants, viruses are considered most destructive among other plant pathogens.

In Indonesia, the most attacking thrips are Thrips parvispinus. In accordance with that proposed by Vos (1994) that one of the adverse thrips species in Southeast Asia is T. parvispinus and is a major constraint on chili cultivation in Java. According to Johari (2017) that $T$. parvispinus is mostly found to attack chili plants in Jambi Province. In addition to the chili plant, $T$. parvispinus is also found in many vegetable crops (Johari, 2015a). Thrips heavy infestation can develop rapidly and need control measures (Johnson, 1995). 
Until now, the method of controlling pests and diseases that are considered highly effective is the chemical method. Chemical pest control is carried out using synthetic insecticides such as Agrimae 8, Decis 25, $2.5 \mathrm{EC}$ and Furdan $3 \mathrm{G}$. The use of synthetic insecticides will manifest negative effects, such as resistance, resurgence, outbreak and the killing of natural enemies. Natural enemies are very important role in the natural control (Funderburk, 2002). Furthermore, Funderburk (2002) states that the ecological effects of synthetic insecticide use include environmental pollution, residue left behind, new chemical resistant pests, increased pest populations, secondary and potential pest raids and increased costs due to chemical dependence.

In order to minimize the negative impacts caused by the use of synthetic insecticides, another alternative to pest control is more environmentally friendly. One alternative that can be done is by biological control. Biological control is the best control of pests in an integrated pest control, because it has a value of continuous contribution (Funderburk, 2002). Biological control can be the use of vegetable insecticides derived from plants.

One of the plants that can be used as a vegetable insecticide is the yam seeds. The results of Nurhakim et al. (2006) found that the use of yam seed extract at a concentration level of $8 \%$ showed results that could suppress the life of Tribolium castaneum. The high mortality of Tribolium castaneum due to the effect of rotenon active compounds contained in the extracts of yam seeds that inhibit metabolic processes in the body. This study aims to analyze the effect of yam seed extract against the phenomenon of thrips attack on chili leaves.

\section{Materials and Methods}

This research was experimental research, using a completely randomized design with treatment of yam seed extract concentration on chili leaf as much as 9 treatments $(0.05 \%, 0.1 \%, 0.5 \%, 1 \%, 1.5 \%$ and $2 \%$, negative control, positive control (chemical insecticide) and methanol/solvent). Each treatment was repeated 4 times, so the total number of experimental units was $9 \times 4$ $=36$ experimental units.

Seeds of $1 \mathrm{~kg}$ of dried beans, are dried at $80^{\circ} \mathrm{C}$ for $2 \times 24 \mathrm{~h}$. Yam seeds are matched using a blender, then sifted, the seed powder of yam is macerated with $2 \mathrm{~L}$ puremethanol for $2 \times 24 \mathrm{~h}$. Furthermore, the filtrate of maceration is filtered with filter paper. The resulting extract was evaporated with a rotary evaporator until methanol was completely vaporized, resulting in $75 \mathrm{~mL}$ thickened solution. The crude extracts were diluted to a concentration of $0.05 \%, 0.1 \%, 0.5 \%, 1 \%, 1.5 \%$ and $2 \%$. Further testing each concentration on the activity of eating thrips on chili leaves. The thrips used are thrips at the imago stage and the chili leaves used are the 3 rd leaf from the leaf buds that have not been affected by disease or pest attack.

Each leaf surface was smeared with crude extract of yam seeds $(0.05 \%, 0.1 \%, 0.5 \%, 1 \%, 1.5 \%, 2 \%)$ and control field. Each leaf that has been smeared with crude extracts is placed in different containers. Each container is filled with 1 sheet of chili leaves that have been smeared extract. Then into each container is inserted 5 imago thrips. This treatment is done as much as $4 \times$ replication. After three days, the remaining leaves of each treatment in the container, measured the width of the stricken leaves using millimeters of the block.

\section{Results and Discussion}

Observation of thrips attack phenomenon was done on the third day by measuring the width of attack leaves using millimeter block. Observations were also made using a Canon EOS 100D camera with $40 \mathrm{~mm} \mathrm{f} / 2.8 \mathrm{G} \mathrm{F}$ S DX Micro Lens. The extensive data of thrips attack on chili leaves obtained by transformation of data (Table 1).

Table 1: Eating activity of Thrips sp. in chili leaves with crude extract of yam seed

\begin{tabular}{|c|c|c|c|c|c|c|c|c|c|}
\hline \multirow[b]{2}{*}{ Repeat } & \multicolumn{9}{|c|}{ Treatment (\%) } \\
\hline & $\mathrm{P} 0$ & $\mathrm{P} 1$ & $\mathrm{P} 2$ & P3 & $\mathrm{P} 4$ & P5 & P6 & $\mathrm{P} 7$ & P8 \\
\hline 1 & 29.450 & 4.05 & 20.780 & 7.4800 & 12.3700 & 4.0500 & 4.05 & 4.05 & 24.0300 \\
\hline 2 & 29.720 & 4.05 & 16.210 & 18.5200 & 12.9100 & 7.4800 & 4.05 & 4.05 & 11.3800 \\
\hline 3 & 29.780 & 4.05 & 26.690 & 10.4600 & 6.2800 & 5.1200 & 4.05 & 4.05 & 17.1400 \\
\hline 4 & 25.830 & 4.05 & 20.340 & 12.3700 & 7.0300 & 4.0500 & 4.05 & 4.05 & 21.1200 \\
\hline Total & 114.780 & 16.20 & 84.020 & 48.8300 & 38.5900 & 20.700 & 16.20 & 16.20 & 73.6700 \\
\hline Average & 28.695 & 4.05 & 21.005 & 12.2075 & 9.6475 & 5.175 & 4.05 & 4.05 & 18.4175 \\
\hline
\end{tabular}

Information: $\mathrm{P} 0=$ Thrips (without the provision of crude extracts of yam seed)

$\mathrm{P} 1=$ Chemical insecticides + Thrips

$\mathrm{P} 2=$ yam seed extract $0,05 \%+$ Thrips

P3 = yam seed extract $0,1 \%+$ Thrips

$\mathrm{P} 4=$ yam seed extract $0,5 \%+$ Thrips

$\mathrm{P} 5=$ yam seed extract $1 \%+$ Thrips

P6 = yam seed extract $1,5 \%+$ Thrips

$\mathrm{P} 7=$ yam seed extract $2 \%+$ Thrips

$\mathrm{P} 8=$ methanol + Thrips 
Table 1 shows that from all the treated concentrations the greatest attack area results $(21.005 \mathrm{~cm})$ were found in the crude extract treatment of $0.05 \%$ concentration and the smallest attack area $(4.05 \mathrm{~cm})$ was present in the $1.5 \%$ concentration treatment and $2 \%$. From these data can be emphasized that the higher the concentration of crude extracts of yam seeds, the less thrips attacks on chili leaves.

Based on statistical analysis using the variance method, it was found that the use of crude extract of yam seeds had a significant effect on the extent of Thrips sp. Duncan's New Multiple Range Test results can be seen in Table 2.

Table 2 confirms that the provision of crude extract of yam seeds significantly affected the extent of the thrips attack $(\alpha=5 \%)$. Based on the statistical analysis of the negative control treatment was significantly different with the positive control treatment and significantly different with the $0.05 \%$ concentration treatment and other treatment. While the positive control treatment was significantly different with $0.05 \%$ concentration treatment and methanol treatment, but not significantly different with treatment of concentration of $1.5 \%$ and $2 \%$.

The treatment was not significantly different from the positive control treatment, so the treatment had the same effect on the extent of thrips attack. The smallest concentration and already able to inhibit the thrips attack on chili leaves is $0.5 \%$. Treatments that inhibited thrips attack were $1.5 \%$ extract concentration, $2 \%$ extract concentration and positive control (chemical insecticide) because there was no attack on the treatment (Fig. 1).

Figure 1 shows a graph of decrease in the area of thrips attack that has started from the lowest treatment concentration $(0.05 \%)$. Decreased area of attack can be caused by the content of rotenon compounds in the seeds of yam which are toxic to insects. According to Novizan (2002) rotenon is an insecticidal compound that is also found in the seeds of yam and plants of the genus tephrosia. Rotenon is a cellular respiratory inhibitor that affects the nerve tissue and muscle cells that cause insects to stop eating. Insect death occurs several hours to several days after exposure to rotenon.

The phenomenon of Thrips sp. the attack can be seen from the extent of the attack, the part of the leaf is attacked, the location of the attack, the color of the attack and attack pattern. Based on the descriptive analysis of the observed results, it was found that the part of the leaf that was attacked by thrips was the top surface. Johari (2015b) found that the thrips released into the confinement that had been previously planted chili planted in polybags, only attack the leaves of the upper surface. Thrips do not attack at one point in the same location. The location of thrips attack on chili leaves is at the tip of the leaf, the middle of the leaf and the base of the leaf.

Table 2: Duncan's new multiple range test, effect of treatment to the extent of Thrips sp. so on chili leaves.

\begin{tabular}{ll}
\hline Treatment & Average area of thrips attack $(\mathrm{Cm})$ \\
\hline P0 & $28,6950^{\mathrm{e}}$ \\
P1 & $4^{\mathrm{a}}$ \\
P2 & $25,7 \mathrm{c}$ \\
P3 & $21 \mathrm{~d}$ \\
P4 & $9,6^{\mathrm{c}}$ \\
P5 & $5,1^{\mathrm{b}}$ \\
P6 & $4^{\mathrm{a}}$ \\
P7 & $4^{\mathrm{a}}$ \\
P8 & $18,4^{\mathrm{d}}$ \\
\hline
\end{tabular}

Information: Figures followed by the same letter show no significant difference

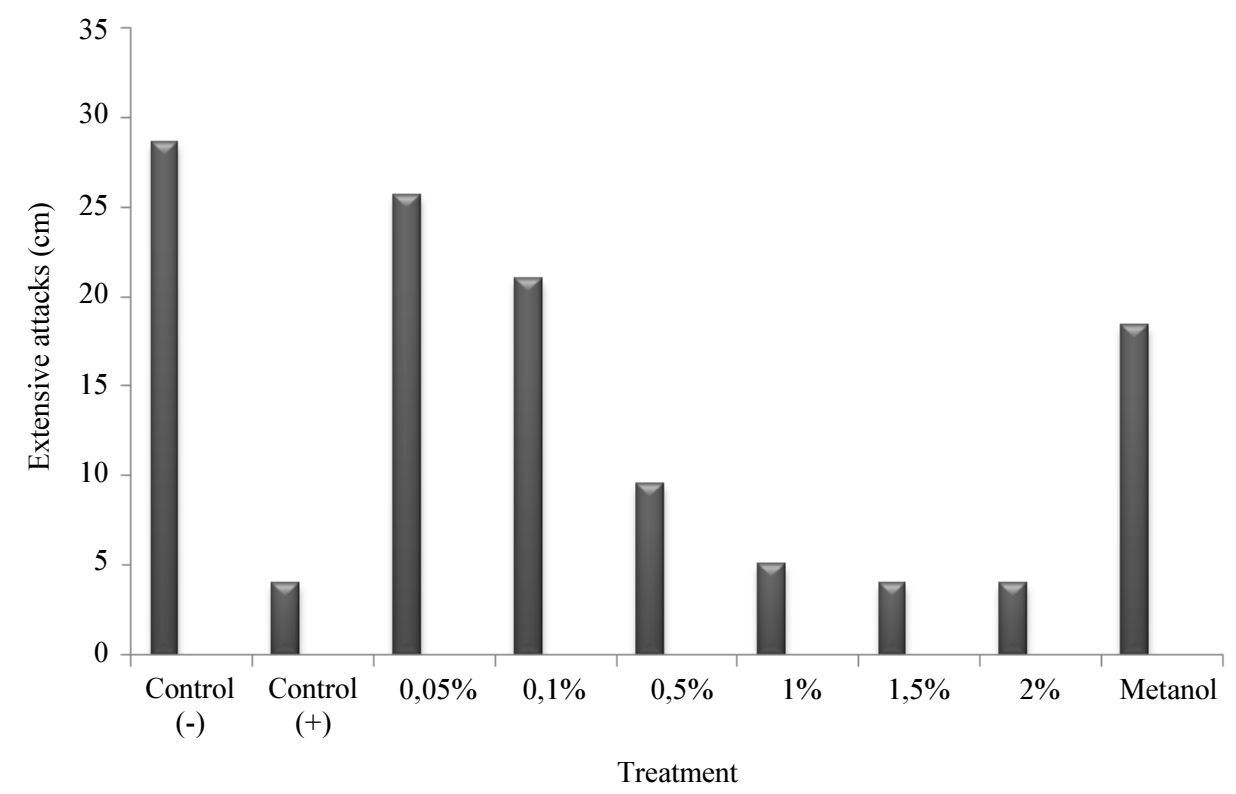

Fig. 1: Graph reduction of Thrips sp attack phenomenon on chili leaves 
In line with research conducted by Johari et al. (2016) that the thrips attack at the base, middle and leaf tips. Thrips can cause attacks. According to Widodo and Sutiyoso (2010), the fluid-sucked plants will leave colored marks on the leaf surface. The color of the thrips attack on chili leaves is silvery and subsequently brownish. The silvery color occurs at the beginning of the attack while the brownish color occurs on the observation of the last day. Johari et al. (2016) also found that early attacks of mild thrips were shown with a silvery color and the color of the attacks turned brownish.

The Thrips also form specific attack patterns and the phenomenon of varied thrips attack patterns. There are 4 patterns of thrips attack on chili leaves are round, oval, elongated and the shape of the Johari et al. (2016) also found that the pattern of thrips attack is rounded, oval, elongated and in the shape of the number 8 . The pattern of attack is formed due to continuous attacks, the mandible sucks fluid in the same position several times a day, so that a certain pattern is formed. The shape of the hole may vary depending on whether the leaf is tested only, superficially examined or deeply investigated (Kirk, 1997).

Different concentrations of the extract are given, indicating the difference in the area of chili leaves that are attacked. The higher the treatment concentration, the smaller the area of chili being attacked due to decreased appetite thrips. Decrease in appetite, due to the effect of crude extract of yam seeds containing rotenon. Rotenon compounds in the seeds of yam can make insects stop eating. According to Novizan (2002) in the seeds of yam, there are rotenon compounds that can inhibit respiration of insect cells that affect the nerve and muscle tissue causing insects to stop eating.

According to Kerkut and Gilbert (1985) when the rotenon enters the digestive system of the insect, rotenon can cause paralysis of the oral devices. Once the rotenon enters the digestive organs, the rotenon compound is absorbed by the intestinal wall and then transited to the nerve center and the respiratory organs so that cell respiration is inhibited. Insect death occurs several hours to several days after exposure to rotenone.

Thrips attack chili leaves by grating and sucking. Symptoms caused by the attack cause silvery spots. Widodo and Sutiyoso (2010) stated that the plants sucked in the liquid will leave a silvery white spot. Next leaf will be brownish and dead. On a great attack the plant part will roll up. According to Boateng et al. (2014) thrips will suck plant fluids and consume mesophyll which eventually leads to the loss of chlorophyll and reduces the efficiency of photosynthesis.

Johari et al. (2016) found that the pattern of thrips attack was round, oval, elongated and forming the number 8 on un-treated chili leaves. While the research using different concentrations of different extracts still found the same pattern, namely the pattern of round, oval, elongated and form the number eight. The pattern of attack is formed by continuous attacks, using the mandibular. Thrips suck fluid in the same position several times a day, so that a certain pattern is formed. According to Johari et al. (2016) pattern number 8, beginning with a single round of attack, then mandibular penetrate the leaves several times a day in different positions, but the position is still adjacent to the former attack before, so that pattern is formed as number 8 . While on the oval pattern, thrips start the attack by forming the margin first, then start attacking with the inward direction. So slowly formed a perfect oval pattern. The pattern of attack also found is the elongated pattern, like a straight line but thicker. According to Johari et al. (2016) mild attacks in the short term cause damage to epidermal cells and the surface of mesophyll cells. While on the longerterm damage can cause severe damage to mesophyll cells and tissues. Damage to plants due to attacks of thrips can be affected by giving of yam seeds.

The giving of yam seeds with varying concentrations has an effect on the extent of attack and activity of thrips to food on chili leaves. The higher the concentration of yam seed extract, the lower the attack produced and the higher the effect of traction antifeedant activity. The lowest attack and the highest antifeedant effect are at a concentration of $2 \%$. This is caused by the pachyrrizid substance contained in the yam seed.

\section{Conclusion}

1. The giving crude extract of yam seed on chili leaves with different concentrations significantly affected the phenomenon of Thrips sp attack

2. The treatment with the highest concentration of crude extract of yam seed (2\%) resulted in the lowest thrips attack on chili leaves and caused the highest antifeedant effect

3. The part of the leaf that is attacked is the top surface of the leaf, with the location of the attack on the base, middle and the tip of the leaf and the entire leaf surface

4. The pattern of thrips attack varies, i.e., round, oval, elongated and the shape of the number 8 and the color of the initial silvery attack, then a brownish color

\section{Acknowledgement}

The authors would like to thank Laurence A. Mound D.Sc. Australian National Insect Collection, CSIRO, Canberra, Australia who helped in identifying the species of thrips.

\section{Author's Contributions}

Tasmin Tangngareng: Compile and write articles thoroughly, translate Indonesian to English, edit 
vocabulary, grammar, writing (words, sentences, tables, pictures), so arranged this manuscript and also help funding.

Asni Johari: Designing research, data retrieval, data analysis, making discussion and responsible research and responsible research fund.

Ratna Sari Dewi: Compile and write articles thoroughly, translate Indonesian to English, edit vocabulary, grammar, writing (words, sentences, tables, pictures), so arranged this manuscript and also help funding

Desfaur Natalia: Helping the implementation of research, data retrieval and data analysis. help with research documentation

Hastutik Setia A and Muhamad Tomy: Helping the implementation of research, data retrieval and data analysis. help with research documentation.

\section{Ethics}

This article is the result of the author's research, so there are no ethical issues

\section{References}

Boateng, C.O., H.F. Schwartz, M.J. Havey and K. Otto, 2014. Evaluation of onion germplasm for resistance to iris yellow spot virus (iris yellow spot virus) and onion thrips, Thripstabaci. Southwest. Entomol., 39: 237-260. DOI: 10.3958/059.039.0218

Funderburk, J., 2002. Ecology of thrips. Proceedings of the 7th International Simposium on Thysanoptera, (IST' 02), pp: 121-128. .

Johari, A., 2015a. The diversity species of thrips sp. (Thysanoptera: Thripidae) in chili plantation (Capsicum annuum L.) in the region of Jambi. Ind. J. Scientific Res. Technol., 3: 65-70.

Johari, A., 2015b. Abundance of Thrips palmi Karny and the phenomenon of Thrips sp. (Thysanoptera: Thripidae) attack as pest and virus vectorat vegetables plantation in Jambi region. ARPN J. Eng. Applied Sci., 10: 2570-22576.

Johari, A., 2017. The abundance of thrips (Thysanoptera) on vegetables plantation in Jambi region, Sumatera, Indonesia. J. Entomol. Res., 41: 25-32. DOI: 10.5958/0974-4576.2017.00005.6
Johari, A., S. Herlinda, C. Irsan and Y. Pujiastuti, 2016. Phenomenon of thrips (Thysanoptera) attack on chili plant (Capsicum annuum L.). Am. J. Agric. Biol. Sci., 11: 103.109.

DOI: 10.3844/ajabssp.2016.103.109

Johnson, M.W., 1995. IPM of Thripspalmi in Vegetables. In: Thrips Biology and Management, Parker, B.L., M. Skinner and T. Lewis (Eds.), Plenum Press, New York, ISBN-10: 0306450135, pp: 381-387.

Kerkut, G.A. and Gilbert, 1985. Insect Control. 1st Edn., Pergamon Press, New York.

Kirk, W.D.J., 1997. Feeding. In: Thrips as Crops Pest, Lewis, T. (Ed.), CAB International University Press, Cambridge, pp: 119-162.

Lakshmi, K.V., J.A. Wightman, D.V.R. Reddy, G.V.R. Rao and A.A.M. Buiel et al., 1995. Transmission of Peanut Bud Necrosis Virus by Thripspalmi in India. In: Thrips Biology and Management, Parker, B.L., M. Skinner and T. Lewis (Eds.), Plenum Press, New York, ISBN-10: 0306450135, pp: 179-184.

Novizan, 2002. Eco-friendly pesticides. PT Agro Media Pustaka, Jakarta.

Nurhakim, A., R. Wiradimadja and I. Hernaman, 2006. Effect of lichen seed extract on life Tribolium castaneum and rough weight in rice storage. Kaunia, 9: 7-7.

Riley, D.G., V.J. Shimat, R. Srinivasan and S. Diffie, 2011. Thrips vectors of tospoviruses. J. Integrated Pest Manage., 1: 1-10. DOI: 10.1603/IPM10020

Ullman, D.E., T.L. German, J.L. Sherwood and D.M. Westcot, 1995. Thrips Transmission of Tospoviruses: Future Possibilities for Management. In: Thrips Biology and Management, Parker, B.L., M. Skinner and T. Lewis (Eds.), Plenum Press, New York, ISBN-10: 0306450135, pp: 3-16.

Vos, J.G.M., 1994. Integrated Crop Management of Hot Pepper (Capsicum spp.) in Tropical Lowlands. 1st Edn., Wageningen Agricultural University, The Netherlands, pp: 188.

Widodo and Y. Sutiyoso, 2010. Pest and disease of early detection and countermeasures. PT Trubus Swadaya, Bogor. 